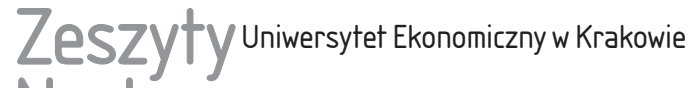 Naukowe
}

$7(955)$

ISSN 1898-6447

Zesz. Nauk. UEK, 2016; 7 (955): 91-108

DOI: 10.15678/ZNUEK.2016.0955.0706

\section{Spór o możliwość i sensowność przypisywania korporacjom moralnej odpowiedzialności. Analiza argumentacji*}

\section{Streszczenie}

Celem artykułu jest próba odpowiedzi na pytanie, czy można przypisywać korporacjom moralną odpowiedzialność. W artykule przeanalizowano stanowiska dotyczące moralnej odpowiedzialności korporacji, poczynając od poglądu negującego taką możliwość, poprzez uznanie, że odpowiedzialność ta opiera się na odpowiednio rozumianej koncepcji moralnej podmiotowości korporacji, aż po stanowisko, zgodnie z którym do przypisania moralnej odpowiedzialności korporacji nie jest konieczne uznanie jej moralnej podmiotowości. W analizie wzięto pod uwagę charakter argumentacji formułowanej przez strony dyskusji, implikacje poszczególnych stanowisk dla teorii interesariuszy oraz wpływ przyjętych rozstrzygnięć na realizację oczekiwań społecznych.

Słowa kluczowe: odpowiedzialność moralna, podmiotowość korporacji, teoria interesariuszy, społeczna odpowiedzialność biznesu.

Klasyfikacja JEL: M14.

Tomasz Kwarciński, Uniwersytet Ekonomiczny w Krakowie, Katedra Filozofii, 31-510 Kraków, ul. Rakowicka 27, e-mail: tomasz.kwarcinski@uek.krakow.pl

* Artykuł powstał w ramach realizacji projektu „Społeczna odpowiedzialność korporacji jako forma odpowiedzialności zbiorowej”, nr 062/WE-KF/01/2014/S/4258, dofinansowanego ze środków na badania statutowe przyznane Katedrze Filozofii Uniwersytetu Ekonomicznego w Krakowie. 


\section{Wprowadzenie}

Artykuł stanowi kontynuację rozważań stanowiących próbę udzielenia odpowiedzi na pytanie, czy na podstawie prezentowanej w literaturze przedmiotu argumentacji można w sposób przekonujący przypisać korporacji moralną odpowiedzialność. W artykule autora dotyczącym stanu badań tej kwestii [Kwarciński 2016] dokonano systematyzacji stanowisk dotyczących moralnej odpowiedzialności korporacji, za podstawę przyjmując stosunek autorów do kwestii moralnej podmiotowości korporacji. Wyróżniono trzy grupy stanowisk: 1) negujące moralną podmiotowość korporacji, a wraz z nią możliwość przypisania korporacjom moralnej odpowiedzialności, 2) aprobujące moralną podmiotowość korporacji oraz ich moralną odpowiedzialność, 3) przypisujące moralną odpowiedzialność korporacji przy jednoczesnym unikaniu przyznawania jej moralnej podmiotowości.

Zwolennicy poglądu negującego moralną podmiotowość korporacji [Friedman 1970, Ladd 1997, Velasquez 1997] swoją argumentację opierają na założeniach indywidualizmu metodologicznego oraz indywidualizmu normatywnego, dochodząc do wniosku, że za działania firmy, których nikt nie planował i nie przewidywał jako możliwego skutku swojego postępowania, a które są rezultatem zazębiających się czynności różnych pracowników korporacji, nikt nie odpowiada. W ten sposób akceptują możliwość występowania skutków, za które nikt nie ponosi odpowiedzialności (problem nieredukowalności), oraz sytuacji, w której może nie być nikogo, kto czuje się zobowiązany do naprawienia powstałych w związku z tym krzywd (problem odpowiedzialności wyrównawczej).

Przedstawione wnioski są nie do zaakceptowania dla zwolenników poglądu aprobującego przypisywanie korporacji moralnej podmiotowości [French 1997, Goodpaster, Matthews 1997, Pettit i List 2011]. Stanowisko to jest jednak wewnętrznie zróżnicowane w zależności od tego, czy akceptowana jest mocna czy słaba forma moralnej podmiotowości. Podmiotowość w sensie mocnym wiąże się z przyznaniem podmiotowi statusu osoby, ze wszystkimi przysługującymi jej prawami i obowiązkami, natomiast podmiotowość w sensie słabym wymaga tylko uznania, że dana organizacja (korporacja) ma zdolność bycia sprawcą (agent).

Autorzy opowiadający się za unikaniem moralnej podmiotowości korporacji [Dempsey 2013, Gibson 2000] uznają, że korporacja jest tego typu bytem, który ponosi odpowiedzialność moralną nawet wtedy, gdy nie jest podmiotem moralnym ani w mocnym sensie bycia osobą, ani w sensie słabym bycia jedynie sprawcą moralnym. Twierdzą bowiem, że fakt, iż korporacja jest systemem skonstruowanym przez podmioty moralne (indywidualnych ludzi) lub iż w ramach korporacji niezależnie od formalnej struktury tworzona jest specyficzna kultura 
organizacyjna, sam w sobie jest wystarczającym uzasadnieniem przypisania korporacji moralnej podmiotowości.

Etap drugi rozważań autora artykułu, następujący po przedstawieniu stanu badań omawianych zagadnień, polega na krytycznej analizie zaprezentowanych stanowisk: zbadaniu charakteru argumentacji formułowanej przez strony dyskusji, przeanalizowaniu implikacji poszczególnych stanowisk dla teorii interesariuszy oraz określeniu wpływu przyjętych rozstrzygnięć na realizację oczekiwań społecznych, które są artykułowane w stosunku do korporacji.

\section{Charakter argumentacji}

\subsection{Uwagi ogólne}

Zarówno zwolennicy, jak i przeciwnicy przypisywania korporacji statusu moralnego odwołują się do dwóch typów argumentacji, są to po pierwsze argumenty z analogii, po drugie argumenty pragmatyczne. Argumentacja przez analogię ma charakter indukcyjny i wymaga wskazania istotnego podobieństwa lub podobieństw między przypadkiem, w którym nie mamy wątpliwości, że dany byt jest osobą (posiada status moralny), a przypadkiem korporacji, o której moralnym statusie chcemy dopiero przesądzić. Krytyka tego typu argumentacji ma na celu wykazanie, że o takim istotnym podobieństwie nie może być mowy.

$\mathrm{W}$ argumentacji pragmatycznej istotne jest wykazanie, że przyznanie korporacji statusu moralnego jest warunkiem koniecznym realizacji pożądanych celów praktycznych, którymi są przede wszystkim możliwość egzekwowania odpowiedzialności wyrównawczej oraz uwzględnienie słusznych racji słabo reprezentowanych interesariuszy. Krytycy tego typu argumentacji starają się pokazać, że wspomniane cele można skutecznie osiągać również wtedy, gdy korporacja jest pozbawiona statusu moralnego. Co więcej, twierdzą oni, że personifikowanie korporacji prowadzi do szeregu trudności, jak podwójne przypisywanie odpowiedzialności (double counting) lub unikanie odpowiedzialności przez zwykłych ludzi.

\subsection{Argumenty $z$ analogii}

Argumentacja z analogii wykorzystywana w sporze o możliwość i sensowność przypisywania korporacji moralnej odpowiedzialności przyjmuje jedną $\mathrm{z}$ trzech form: 1) formę ontologiczną, gdy twierdzi się, że natura korporacji, przede wszystkim przez jej wewnętrzną strukturę decyzyjną, jest w jakiś sposób podobna do natury zwykłych ludzi; 2) formę epistemologiczną, gdy uznaje się, że korporacja ma zdolność formułowania swoich przekonań na temat rzeczywistości 
w sposób podobny do zwykłych ludzi, oraz 3) formę semantyczną, gdy uważa się, że takie kategorie moralne jak prawo, obowiązek, cnota, wada, wina i kara mogą być stosowane do korporacji w podobnym sensie, w jakim są odnoszone do zwykłych ludzi.

Jednym z kluczowych założeń zwolenników przypisywania korporacjom moralnej osobowości jest możliwość przeprowadzenia wyraźnej granicy między grupami dobrze ustrukturyzowanymi (konglomeratami), takimi jak korporacja a zgromadzeniami ludzi o luźnej strukturze organizacyjnej (agregatami), takimi jak tłum. Jak zauważono w pracy [Kwarciński 2016], P.A. French uznaje, że tylko konglomeratom należy się status podmiotów moralnych, gdyż tylko one charakteryzują się: wewnętrzną organizacją i procedurami decyzyjnymi, egzekwowaniem obowiązujących standardów zachowań oraz definiowaniem ról organizacyjnych, za których pośrednictwem jedni członkowie organizacji realizują swoją władzę nad innymi.

W praktyce jednak możliwość wskazania takiej linii demarkacyjnej wydaje się mocno ograniczona. Zdaniem R. Pfeiffera [1990, s. 475] również grupy typu agregatowego mogą czasem wykazywać własności zbliżone do wskazanych przez Frencha. Z drugiej zaś strony grupy, które określamy mianem konglomeratów, mogą czasem utracić wyróżniające je właściwości, rozluźniając swoją strukturę organizacyjną, jak np. korporacja, w której zaczyna panować chaos decyzyjny [Moore 1999, s. 334]. Wątpliwość ta nie stanowi jednak rozstrzygającego argumentu przeciwko możliwości przypisywania konglomeratom moralnej podmiotowości. Jest raczej sugestią, że podmiotowość moralna może mieć charakter stopniowalny [Moore 1999, s. 334], zależny od tego, w jakim stopniu funkcjonowanie organizacji opiera się na wewnętrznej strukturze decyzyjnej, i charakter czasowy ${ }^{1}$.

Trudności z utrzymaniem analogii osoba-korporacja stają się zdaniem takich autorów jak M.G. Velasquez [2003] czy N. Ranken [1987] widoczne, gdy przyjrzymy się problemowi intencjonalności działań i wewnętrznej motywacji korporacji. Zdaniem Velasqueza nie ma faktycznie żadnych podstaw do uznania, że przypisywanie korporacji intencjonalności ${ }^{2}$, czyli celowego, zamierzonego działania, jest czymś więcej niż metaforycznym sposobem wysławiania się. Wewnętrzna struktura decyzyjna korporacji nie sprawi, że korporacja zacznie działać inten-

1 Przekonanie o stopniowalności i czasowości osobowego statusu korporacji jest zgodne z deskryptywną koncepcją osoby wprowadzoną przez J. Locke’a, nie da się go jednak pogodzić z poglądami Boecjusza, na które powołuje się French. Boecjusz uznawał bowiem, że w związku z tym, iż do istoty człowieka należy rozumność, to pozostaje on osobą bez względu na to, czy i jak dalece jest w stanie tę rozumność przejawiać w praktyce.

2 Przyjmuje się, że podmiot działa w sposób intencjonalny, gdy zmierza mniej lub bardziej racjonalnie do realizacji swoich pragnień (celów), opierając się na żywionych przez siebie przekonaniach [Pettit i List 2011, s. 13]. 
cjonalnie, dokładnie tak samo jak, przynajmniej czasami, robią to ludzie z krwi i kości. Możemy najwyżej powiedzieć, że firma działa „tak jakby” intencjonalnie. Owa intencjonalność korporacji polega bądź na tym, że grupie, którą jest korporacja, przypisujemy intencjonalność, dostrzegając w niej jakąś analogię do nas samych, bądź na tym, że deklarujemy, iż dany sposób funkcjonowania korporacji będziemy odtąd uznawać za działania intencjonalne [Velasquez 2003, s. 549]. Za każdym razem jednak podstawa do uznania intencjonalności korporacji tkwi w nas samych (realnych ludziach, obserwatorach funkcjonowania korporacji), a nie w sposobie funkcjonowania samej korporacji. Za każdym razem jest to bardziej kwestia naszego sposobu mówienia o świecie niż samej rzeczywistości.

M. Velasquez ma rację, twierdząc, że intencjonalność korporacji nie ma dokładnie takiego samego charakteru jak intencjonalność zwykłych ludzi; korporacje nie mają umysłu, a przynajmniej nie mają umysłu dokładnie takiego jak my. Jest to jednak dosyć trywialna konstatacja. Nietrywialne jest natomiast rozróżnienie intencjonalności przypisywanej korporacji (descriptive attribution) oraz intencjonalności deklarowanej (prescriptive attribution) wobec działań podejmowanych przez korporację [Velasquez 2003, s. 548]. Choć ten drugi sposób mówienia o intencjonalności bez wątpienia ma źródło poza samą korporacją (w podmiocie deklarującym), nie musi tak być w przypadku intencjonalności przypisywanej korporacji. Być może sposób mówienia niektórych z nas (np. zwolenników personifikowania korporacji) ma jednak pewne oparcie w rzeczywistości, a „tak jakby” intencjonalne działania korporacji mają jakieś cechy wspólne z działaniami sensu stricto intencjonalnymi, które podejmują zwykli ludzie ${ }^{3}$. Taką cechą jest dla niektórych autonomia podmiotu.

Drugim problemem dotyczącym budowania analogii między człowiekiem-osobą a korporacją-osobą jest kwestia wewnętrznej motywacji korporacji. Zdaniem N. Ranken [1987, s. 634] podstawowa różnica między człowiekiem a korporacją polega na tym, że ten pierwszy, by stać się odpowiedzialnym, musi rozwinąc swoje dyspozycje, dobrze ukształtować własny charakter, natomiast korporacja staje się odpowiedzialna wówczas, gdy zinstytucjonalizuje cechy, które zwykliśmy łączyć z odpowiedzialnością (np. przewidywanie wpływu swojego funkcjonowania na interesariuszy). Jednak podczas gdy człowiek jest w stanie sam siebie zmotywować do pracy nad własnym charakterem (rozwijania swoich cnót moralnych), korporacja nie jest zdolna sama siebie zmotywować do zinstytucjonalizowania czegokolwiek. Sama jest bowiem jedynie instytucją powołaną do życia przez inną instytucję, czyli prawo. W związku z tym może być zmieniana tylko od zewnątrz, przez ludzi, brak jej wszakże wewnętrznego

${ }^{3}$ I. Ashmani i D. Winstanley [2007, s. 88] nie zgadzają się z tym stwierdzeniem. Wskazują, że intencjonalność zwykłych ludzi ma aktywny, a nie pasywny charakter jak w przypadku korporacji. 
mechanizmu motywacyjnego, który byłby podobny do tego posiadanego przez zwykłych ludzi.

Zwolennicy przyznania korporacji podmiotowości w sensie słabym [Pettit i List 2011] zgadzają się z krytykami stanowiska personifikującego korporację w tym, że korporacja nie ma autonomii ontycznej, twierdzą jednak, że podobnie do zwykłych ludzi posiada ona autonomię epistemiczną. Korporacja nie ma np. wrażliwości na los innych ludzi, brak jej także wewnętrznej motywacji oraz życia emocjonalnego. W związku z tym nie przysługują jej prawa przynależne osobie, choć zasługuje na przypisanie moralnej odpowiedzialności.

Brak analogii dotyczący motywacji człowieka i instytucji, którą jest korporacja, leży u podstaw wątpliwości związanych z możliwością odnoszenia do niej pojęć moralnych, takich jak prawo, obowiązek, cnota, wada, wina i kara. Podstawowe (naturalne) prawa przynależne ludziom jako podmiotom moralnym to m.in. prawo do życia, wolności i własności (Locke). Krytycy moralnej podmiotowości korporacji wskazują, że przyznanie tego typu praw podmiotom zbiorowym prowadzi do osobliwych wniosków - jednym z nich jest przekonanie, że wrogie przejęcie jednej firmy przez drugą jest rodzajem morderstwa lub niewolnictwa [Manning 1988]. Korporacja nie jest nosicielem praw moralnych, ponieważ nie ma wrażliwości, którą posiadają zwykli ludzie [Hindriks 2014, s. 1583]. Trudno oczekiwać, by firma rozwinęła w sobie poczucie dobra i zła, trudno również spodziewać się, że będzie się ona przejmować losem innych firm i ludzi. Od korporacji można wymagać jedynie tego, by wypełniała swoje obowiązki. Jeśli jednak jakiś podmiot ma obowiązki, to wydaje się, że powinny mu być również przynależne pewne prawa. Na tę wątpliwość można odpowiedzieć w dwojaki sposób. Zauważmy, po pierwsze, że obowiązkom jednych podmiotów odpowiadają prawa innych. Nie musi być zatem tak, że uznanie, iż korporacja ma obowiązek poszanowania przynależnego człowiekowi prawa do życia, prowadzi nas niezawodnie do wniosku, że jej samej również przysługuje identyczne prawo. Po drugie korporacja może mieć prawa i obowiązki wynikające z oczekiwań społecznych lub nakazów prawnych. Nie wydaje się niespójny pogląd, zgodnie z którym korporacja, sama nie posiadając praw moralnych, jest zobowiązana (ze względu na prawo lub oczekiwania społeczne) do podejmowania określonych działań w celu ochrony praw moralnych zwykłych ludzi.

Inna wątpliwość związana z odnoszeniem pojęć moralnych do korporacji dotyczy mówienia o jej cnotach lub wadach. $\mathrm{O}$ ile korporacja może np. wypełniać obowiązki sprawiedliwości, o tyle nie jest ona jednak w stanie wyrobić w sobie cnoty sprawiedliwości. Korporacja, nie mając życia emocjonalnego takiego jak zwykli ludzie, nie może samodzielnie kształtować swojego charakteru i kierować się motywacją podobną do ludzkiej [Ewin 1991, s. 751-753]. Jeśli funkcjonowanie korporacji jest zgodne z obowiązkami sprawiedliwości, nie musi to oznaczać, że 
obchodzi ją sprawiedliwość ani że poczucie sprawiedliwości jest zasadniczym motywem jej „postępowania”. Wystarczy, że zinstytucjonalizuje ona wymogi sprawiedliwości, których oczekuje społeczeństwo.

Oba sformułowane tu argumenty, czyli argument braku wrażliwości oraz argument braku życia emocjonalnego, mają charakter argumentów ontologicznych, ale przesądzają o niemożliwości zastosowania do korporacji takich pojęć moralnych jak prawa czy cnoty, co z kolei każe podać w wątpliwość tezę głoszącą, że korporacja jest sensu stricto osobą. Gdyby wspomniane argumenty okazały się niewystarczające, przeciwnicy personifikowania korporacji wskazują na problemy związane z odnoszeniem do korporacji kategorii winy i kary. Zgodnie ze zdroworozsądkowym przekonaniem ukarana powinna być wyłącznie osoba winna popełnienia nagannych czynów. Nawet jeśli zgodzimy się, że w pewnych sytuacjach winę za wywołanie negatywnych skutków ponosi korporacja jako taka, a nie któryś z jej pracowników, to i tak kara za takie działanie zostanie ostatecznie przerzucona na tych właśnie ludzi. Korporacji jako organizacji nie sposób bowiem uwięzić, a jej likwidacja lub nakaz zapłaty wysokiej grzywny z pewnością odbije się na jej interesariuszach. W stosunku do tego stanowiska G. Moore [1999, s. 337] zgłasza dwie wątpliwości. Po pierwsze zauważa, że również kara nakładana na indywidualnych ludzi nie pozostaje bez wpływu np. na ich najbliższych, w związku z czym trudno jest oczekiwać, by kara do pewnego stopnia nie dotykała również osób niezaangażowanych w popełnienie nagannego czynu. Po drugie, twierdzi Moore, można uznać, że ludzie, którzy decydują się pracować $\mathrm{w}$ danej firmie, identyfikują się z nią i w związku z tym przyjmują na siebie odpowiedzialność za działania organizacji, której są członkami.

O ile pierwszy, pragmatyczny argument, wydaje się dość przekonujący, o tyle argument z członkostwa przesuwa problem z odpowiedzialności kolektywnej na odpowiedzialność zbiorową. Jeśli uznamy, że każdy z członków odpowiada za działania całej grupy, to cały problem odpowiedzialności korporacyjnej przestaje istnieć, a w związku z tym przestaje mieć znaczenie to, czy korporacji można przypisać takie pojęcia moralne jak wina i kara.

Podsumowując, najmniej wątpliwości budzi argumentacja epistemiczna. Analizowany w artykule [Kwarciński 2016] argument P. Pettita i Ch. Lista, w którym odwołują się do dylematu dyskursywności, wydaje się przekonujący. Konglomerat, którym jest korporacja, poprzez sposób podejmowania decyzji staje się podobny do zwykłego człowieka w tym, że decyzje te są niezależne od woli innych pomiotów, w tym ludzi tworzących tę korporację. Najmniej przekonuje argumentacja ontologiczna i oparta na niej argumentacja semantyczna. Krytycy skutecznie wskazują na brak po stronie korporacji wielu istotnych cech, które zazwyczaj łączymy z moralną podmiotowością ludzi. Wnioski, zgodnie 
z którymi wrogie przejęcie jednej firmy przez drugą jest rodzajem morderstwa lub niewolnictwa, można interpretować jako próbę sprowadzenia argumentacji semantycznej ad absurdum.

\subsection{Argumenty pragmatyczne}

Zgodnie z argumentacją pragmatyczną uznanie moralnej odpowiedzialności korporacji sprzyja realizacji celów praktycznych. W tym kontekście wymienia się przede wszystkim realizację wymogów odpowiedzialności wyrównawczej oraz uwzględnianie w procesie decyzyjnym korporacji słusznych racji słabo reprezentowanych grup interesariuszy.

Odpowiedzialność wyrównawcza domaga się wskazania podmiotu, który byłby odpowiedzialny za naprawienie wyrządzonej krzywdy. Przykładowo do katastrofy tankowca Exxon Valdez u wybrzeży Alaski, która miała miejsce w 1989 r., doprowadziło nie tylko pijaństwo kapitana, ale również ignorowanie tego faktu przez jego przełożonych oraz liczne zaniedbania dotyczące technicznego wyposażenia statku ${ }^{4}$. Stajemy przed problemem praktycznym, kto i w jakim stopniu w takich sytuacjach powinien ponosić koszty naprawienia szkód. Poza tym skala zniszczeń może być tak duża, że poszczególni pracownicy, nawet jeśli wydatnie przyczynili się do katastrofy, mogą być niezdolni do ich zrekompensowania. Rozumowanie zwolenników personifikowania korporacji w tym punkcie jest klarowne - odpowiedzialność wyrównawcza w takich przypadkach spoczywa na korporacji jako takiej, a nie na którymś z jej pracowników. W ten sposób unikają oni również teoretycznego problemu nieredukowalności, zawsze bowiem istnieje podmiot odpowiedzialny za wywołanie danych skutków, są to bądź indywidualni ludzie, np. pracownicy firmy, bądź sama korporacja jako odrębny byt. Upodmiotowienie korporacji daje nadzieję na realizację sprawiedliwości wyrównawczej [Ashman i Winstanley 2007, s. 92].

Zaprezentowane rozumowanie, choć spójne, wydaje się jednak mało przekonujące. Kwestie odpowiedzialności wyrównawczej można bowiem rozstrzygnąć na drodze czysto konwencjonalnej. Ewentualnie można opowiedzieć się za którąś ze strategii unikających przypisywania korporacji statusu moralnego bez jednoczesnego pozbawiania jej moralnej odpowiedzialności. Na przykład uznając, że korporacja jest systemem moralnie znaczącym, „nadwyżkową” odpowiedzialność można przypisać samemu systemowi. W każdym razie zwolennicy personifikowania korporacji dalecy są od wykazania, że takie założenie stanowi warunek konieczny rozwiązania problemu odpowiedzialności wyrównawczej.

${ }^{4}$ Raport Narodowej Rady Bezpieczeństwa Transportu USA (NTSB) część winy przypisuje również nieodpowiedniemu systemowi regulacji ruchem, który stosowała amerykańska straż przybrzeżna, http://www.britannica.com/event/Exxon-Valdez-oil-spill (data dostępu: sierpień 2016). 
Bardziej obiecujący argument oparty jest na wymogu uwzględnienia w procesie decyzyjnym spółki stanowiska także tych grup interesariuszy, które w ramach tego procesu są słabo reprezentowane lub nie są reprezentowane wcale [Goodpaster i Matthews 1997, s. 106, 114]. Może się na przykład zdarzyć, że rdzenna ludność na terenach eksploatowanych przez korporację nie będzie miała wystarczających środków, by zabezpieczyć swoje prawa. Jeśli korporacja jest podmiotem moralnym, to $\mathrm{w}$ takiej sytuacji w swoich decyzjach powinna uwzględnić interesy także tych, którzy nie wywierają na jej działalność istotnego wpływu, ale sami takiemu wpływowi podlegają. Zakłada się tutaj bezwarunkowość obowiązków moralnych. Zauważmy, że zgoda na przypisanie korporacjom moralnej podmiotowości pociąga za sobą nie tylko uznanie ich społecznej (wrażliwej na oczekiwania empiryczne i normatywne), ale i moralnej (bezwarunkowej) odpowiedzialności za swoje działania.

Argumentacja pragmatyczna jest osłabiana przez to, że personifikacja korporacji prowadzi do generowania nowych problemów, wśród których najczęściej podnoszone są: zagrożenie podwójnym przypisywaniem odpowiedzialności, unikanie odpowiedzialności i groźba podporządkowania jednostek zbiorowości.

Problem podwójnego przypisywania odpowiedzialności (double counting) powstaje w związku z przyznaniem korporacji statusu podmiotowego, który sprawia, że tworzący ją ludzie zdają się odpowiadać podwójnie za wywołanie jednorazowego skutku, raz jako indywidualne podmioty, drugi raz jako członkowie korporacji [Gibson 2000, s. 251, 253]. Pojawia się tutaj, analizowana przy okazji argumentacji z analogii, kwestia adekwatności winy i kary poszczególnych ludzi.

Upodmiotowienie korporacji wydaje się stanowić zagrożenie dla idei moralnej odpowiedzialności indywidualnych ludzi. Problem ten jest widoczny w argumentacji Velasqueza [1997, s. 150, 151]. Z jednej strony twierdzi on, że uznanie korporacji za podmiot moralnej odpowiedzialności sprawi, iż będziemy skrywać winę jednostek za zasłoną odpowiedzialności korporacyjnej i zamiast karać winnych, poprzestaniemy na bezskutecznych gestach wobec firmy. $\mathrm{Z}$ drugiej zaś strony uważa, że uznanie korporacji za podmiot moralny, czyli rodzaj organizmu, którego komórkami są indywidualni ludzie, doprowadzi do zakwestionowania autonomii poszczególnych ludzi, którzy, jako części większej całości, zaczną być traktowani instrumentalnie. Personifikacja korporacji zagraża więc idei indywidualnej odpowiedzialności w dwojaki sposób, bądź jako rodzaj uniku, bądź jako rodzaj podporządkowania jednostki większej całości. Pierwsze z wymienionych zagrożeń jest związane z zakwestionowaniem indywidualizmu normatywnego, $\mathrm{w}$ przypadku drugiego z nich podważony zostaje również indywidualizm metodologiczny. 


\section{Implikacje dla teorii interesariuszy}

\subsection{Uwagi ogólne}

W ramach ekonomii neoklasycznej twierdzi się, że główną funkcją przedsiębiorstwa jest generowanie zysków dla właścicieli, czyli osób bądź instytucji posiadających udziały w firmie (shareholders). W połowie lat osiemdziesiątych ubiegłego wieku w teorii zarządzania zapoczątkowany został nowy trend, w którym uznano, że podejmując strategiczne decyzje, firma musi brać pod uwagę wpływ, jaki będą one wywierać na różne grupy interesariuszy (stakeholders) [Freeman 1984].

Przez interesariuszy danej firmy zazwyczaj rozumie się poszczególnych ludzi, grupy i organizacje, których interesy są związane $\mathrm{z}$ funkcjonowaniem firmy (wdrażanymi procesami i osiąganymi rezultatami) oraz od których zależy realizacja celów firmy. Wyróżnia się tzw. interesariuszy podstawowych (primary stakeholders) oraz interesariuszy drugorzędnych (secondary stakeholders) ${ }^{5}$, do grona tych pierwszych zaliczając pracowników, menedżerów, akcjonariuszy, dostawców, instytucje finansowe, konsumentów, zaś w drugiej grupie umieszczając społeczności lokalne, grupy zaangażowane w realizację celów społecznych lub ochronę środowiska, media bądź nawet społeczeństwo jako całość [Harrison, Freeman i Cavalcanti Sá de Abreu 2015, s. 859].

Główna teza teorii interesariuszy głosi, że proces zarządzania firmą jest nastawiony na realizację interesów i osiąganie dobrobytu jej interesariuszy. Twierdzi się ponadto, że tak zarządzane przedsiębiorstwa będą w stanie osiągać przewagę konkurencyjną [Harrison, Bosse i Phillips 2012].

Teoria interesariuszy daje się interpretować na trzy sposoby: 1) jako teoria deskryptywna, 2) jako teoria instrumentalna oraz 3) jako teoria normatywna. Teoria interesariuszy ma charakter deskryptywny, gdyż prezentuje model opisujący, czym jest firma. Teoria ta ma również charakter instrumentalny, ponieważ rozważa się w niej związek między zarządzaniem interesariuszami a osiąganiem przez firmę celów biznesowych (zysku). Wreszcie teorii interesariuszy nadaje się interpretację normatywną, zgodnie z którą przynajmniej niektóre interesy poszczególnych grup interesariuszy mają wartość „,wewnętrzną” (są uzasadnionymi interesami), czyli niezależną od korzyści, które w związku z ich zaspokojeniem może osiągnąć firma. Twierdzi się ponadto, że korporacja powinna w miarę możliwości dążyć do równoczesnej realizacji uzasadnionych interesów (legitimate interests) swoich interesariuszy [Donaldson i Preston 1995, s. 66, 67].

${ }^{5}$ Występują różne sposoby kategoryzacji interesariuszy, a samo pojęcie interesariuszy jest przedmiotem licznych kontrowersji [Miles 2015]. 
Wyróżnienie normatywnej interpretacji teorii interesariuszy, powiązane z przekonaniem, że rdzeń tej teorii ma charakter normatywny [Donaldson i Preston 1995, s. 74] dało impuls do poszukiwania moralnych podstaw teorii interesariuszy [Gibson 2000]. Upatrywanie ich zaś w etyce deontologicznej zdaje się domagać przyznania korporacji statusu moralnego.

\subsection{Deontologizm jako podstawa teorii interesariuszy}

Zgodnie z teorią interesariuszy zarządzający korporacją, podejmując decyzje, powinni brać pod uwagę interesy różnych ludzi, grup oraz instytucji, na które firma wywiera wpływ i (lub) które mogą wywierać wpływ na firmę. Ten sam człowiek może być jednak akcjonariuszem, pracownikiem, członkiem społeczności lokalnej czy konsumentem. Oznacza to, że jednocześnie jest członkiem różnych grup, które stawiają sobie odmienne cele i mają sprzeczne interesy. Skoro zaś cele grup są odmienne od celów i interesów tworzących je ludzi, a ponadto jeśli uzasadnione interesy grup mają również wartość „wewnętrzną”, teoria interesariuszy zdaje się wymagać przyznania statusu moralnego takim podmiotom zbiorowym jak korporacje lub inne organizacje [Gibson 2000, s. 251].

Zaprezentowane rozumowanie prowadzi do wniosku, że jeśli teoria interesariuszy ma być w pełni stosowalna, musi zakładać nadanie korporacji statusu moralnego. Założenie to jest jednak zbyt mocne, i to co najmniej z dwóch powodów. Po pierwsze można konsekwentnie utrzymywać, że odpowiedzialność korporacji nie sprowadza się wyłącznie do odpowiedzialności tworzących ją ludzi, bazując na strategiach unikania moralnej podmiotowości korporacji. W artykule [Kwarciński 2016] poddano analizie dwa stanowiska składające się na tę strategię, były to: traktowanie korporacji jako systemu moralnie znaczącego oraz zwrócenie uwagi na rolę kultury organizacyjnej w korporacji. Po drugie rozumowanie to wymaga, by status podmiotowy został nadany nie tylko korporacjom, lecz także wszystkim grupowym interesariuszom korporacji.

\subsection{Personifikacja interesariuszy}

Jeśli zgadzamy się z poglądem personifikującym korporację, to w ramach teorii interesariuszy musimy również być skłonni do uznania, że korporacja sama jest jednym z interesariuszy oraz że instytucjonalni, grupowi interesariusze (np. inne firmy lub organizacje) również mają podmiotowość moralną. W związku z tym dochodzimy do wniosku, że nie tylko korporacje jako podmioty moralne mają obowiązki względem indywidualnych ludzi, lecz także mają takie obowiązki względem innych bytów zbiorowych (firm bądź organizacji) niezależnie od tego, jakie obowiązki spoczywają na tworzących je ludziach. Ponadto powstaje problem, czy jeśli indywidualni interesariusze zaczynają działać 
wspólnie, powinniśmy traktować ich wyłącznie jako agregaty jednostek czy też jako konglomeraty, którym przysługują prawa i obowiązki moralne [Moore 1999, s. 340, 341].

Przyznanie korporacjom statusu moralnego w powiązaniu z teorią interesariuszy w istotny sposób komplikuje moralny ogląd rzeczywistości, multiplikując byty, którym przynależne są prawa i obowiązki moralne, oraz zwielokrotniając relacje o charakterze moralnym. Powstaje pytanie, czy takie założenia są konieczne i czy rdzeń teorii interesariuszy ma rzeczywiście normatywny charakter.

\subsection{Preskryptywność vs normatywność teorii interesariuszy}

Można wskazać co najmniej cztery powody, dla których zaleca się, by zarząd traktował wszystkich interesariuszy z szacunkiem, a nawet z hojnością: 1) przyczynia to się do realizacji długoterminowych celów firmy, 2) takie są oczekiwania społeczne, 3) interesy każdego z intersariuszy są ważne same w sobie (mają wartość „wewnętrzną”) oraz 4) korporacja jest podmiotem moralnym, na którym spoczywają moralne obowiązki.

Każdy z wyróżnionych powodów wystarcza do uznania, że teoria interesariuszy ma charakter preskryptywny (zalecający określone działania), lecz tylko dwie ostatnie racje wskazują na normatywność tej teorii. Preskryptywność bowiem obejmuje zarówno instrumentalne powody troski o interesariuszy (imperatywy hipotetyczne), jak i bezwarunkowe racje (imperatywy kategoryczne) spełniania wymogów sprawiedliwości [Donaldson i Preston 1995, s. 72]. Twórcy teorii interesariuszy zwracają uwagę, że teoria ta jest teorią zarządzania, a nie koncepcją społecznej odpowiedzialności biznesu (CSR) lub etyką biznesu [Harrison, Freeman i Cavalcanti Sá de Abreu 2015, s. 860]. Nie wszyscy interesariusze są równie ważni dla korporacji; istotni są ci, którzy mają wpływ na osiągnięcie długofalowych celów firmy. Co więcej, uznanie, że interesy wszystkich interesariuszy są równie ważne, stało się jedną z barier rozwoju teorii interesariuszy [Freeman i McVea 2001].

Przyznanie korporacji osobowego statusu pozwala wprawdzie na zastosowanie do niej teorii moralnych takich jak kantyzm, etyka cnót czy teoria umowy społecznej, jest to jednak wyjście poza teorię zarządzania w kierunku poszukiwania jej filozoficznego uzasadnienia. Uzasadnienie to może mieć także charakter utylitarystyczny i odwoływać się nie do bezwarunkowych obowiązków moralnych, lecz do konieczności maksymalizowania dobrobytu jak największej liczby ludzi. Jest tylko jeden powód, dla którego personifikowanie korporacji może mieć znaczenie w teorii interesariuszy - jest nim możliwość uwzględnienia stanowiska tych, których racje są słabo reprezentowane. Jeśli jednak teoria ta 
programowo odrzuca tezę, zgodnie z którą interesy wszystkich stron mają taką samą wartość, to przedstawiona argumentacja przestaje być przekonująca.

Okazuje się, że stanowiska personifikujące korporacje nie wnoszą do teorii interesariuszy istotnych rozstrzygnięć. Co więcej, generują rozmaite problemy natury ontologicznej, moralnej i semantycznej. Pragmatyczne podejście do zarządzania interesariuszami wydaje się wystarczające dla realizacji przez korporację jej długofalowych celów, do czego teoria ta ma się przyczyniać [Freeman i McVea 2001].

\section{Oczekiwania spoleczne wobec korporacji}

Można wyróżnić cztery główne rodzaje oczekiwań zgłaszanych przez społeczeństwo wobec korporacji; są to oczekiwania o charakterze: 1) ekonomicznym, 2) prawnym, 3) etycznym oraz 4) filantropijnym. W pierwszej kolejności oczekuje się, że firma będzie produkować dobra lub świadczyć usługi, których społeczeństwo potrzebuje, osiągając przy tym zysk. Dalej społeczeństwo oczekuje, że firma będzie realizować swoje zadania ekonomiczne, mieszcząc się w granicach prawa. Oczekiwania o charakterze etycznym ${ }^{6}$ to (w tradycji anglosaskiej) stawiane firmie przez społeczeństwo wszelkie wymagania, które wykraczają poza zakres obowiązków prawnych. Wreszcie oczekuje się również, że osoby kierujące firmą będą podejmować dobrowolne działania o charakterze filantropijnym skierowane na osiąganie określonych celów społecznych [Carroll 1979, s. 499].

Wymienione oczekiwania są w sposób spójny formułowane w ramach koncepcji społecznej odpowiedzialności biznesu (CSR). W artykule [Kwarciński 2016] CSR scharakteryzowane zostało jako sposób zarządzania przedsiębiorstwem, w ramach którego odpowiada się na możliwe do zidentyfikowania oczekiwania interesariuszy, co ma zapewnić firmie uzyskanie przewagi konkurencyjnej oraz prowadzić do trwałego rozwoju ekonomicznego i społecznego. Zwróćmy uwagę na trzy kwestie związane z przedstawionym sformułowaniem. Po pierwsze nacisk jest tam położony nie na odpowiedzialność moralną firmy, lecz na to, że powinna ona odpowiadać na oczekiwania interesariuszy ${ }^{7}$. Po drugie w świetle tej definicji funkcjonowanie firmy powinno być oceniane nie tylko przez pryzmat osiąganych celów biznesowych (maksymalizacja zysku), lecz także z punktu widzenia realizacji celów społecznych i troski o środowisko naturalne (trwały,

${ }^{6}$ Oczekiwania etyczne należy łączyć z etosem danej społeczności, czyli z dobrym obyczajem, dotyczącym tego, jak należy postępować.

${ }^{7}$ W. Frederick [1994] określa to jako przejście od corporate social responsibility (CSR1) do corporate social responsiveness (CSR2). 
zrównoważony rozwój). Jest to tzw. potrójne kryterium oceny (triple bottom line). Po trzecie przedstawiona charakterystyka CSR odwołuje się do teorii interesariuszy, chociaż się z nią nie utożsamia ${ }^{8}$.

Oczekiwania społeczne dotyczą zarówno eliminowania negatywnych zachowań i naprawiania spowodowanych przez nie szkód (odpowiedzialność negatywna), jak i wnoszenia pozytywnego wkładu do społeczeństwa (odpowiedzialność pozytywna). Wymóg ponoszenia odpowiedzialności negatywnej pokrywa się z argumentacją pragmatyczną, w ramach której postuluje się, by korporacja realizowała wymagania sprawiedliwości wyrównawczej.

Kwestią otwartą pozostaje to, jak daleko sięga odpowiedzialność korporacji. W ramach takich inicjatyw jak Global Compact czy norma ISO 26000 wykorzystano koncepcję tzw. sfery wpływu (sphere of influence), zgodnie z którą korporacja jest odpowiedzialna w obszarze swojej sfery wpływu. Choć krytycy wskazują na nieostrość tego sformułowania, zazwyczaj rozumie się przez nie cały łańcuch wartości firmy. Wyróżnia się również wpływ o charakterze bezpośrednim, związany z działaniami korporacji, oraz wpływ pośredni, który korporacja może wywierać na tych, z którymi w jakiś sposób ma do czynienia, np. kooperantów, administrację rządową [Wood 2011]. Wskazane inicjatywy odwołują się również do języka praw człowieka. Wymaga się bowiem, by firmy szanowały prawo do życia, zdrowia, edukacji, pracy itp. i promowały poszanowanie takich praw w obszarach swoich sfer wpływu.

Jakie znaczenie dla realizacji oczekiwań społecznych może mieć akceptacja któregoś ze stanowisk w kwestii moralnej odpowiedzialności korporacji? Z jednej strony kuszącym rozwiązaniem jest przyjęcie, że skoro mamy wymóg odpowiedzialności, przedmiot tej odpowiedzialności, którym są kwestie wyrażane w oczekiwaniach społecznych, i podmiot, wobec którego ta odpowiedzialność jest podejmowana, czyli społeczeństwo, to możemy jasno wskazać, na kim ta odpowiedzialność spoczywa, czyli uznać korporację za podmiot moralny. Otrzymujemy więc prosty schemat, w którym społeczna odpowiedzialność biznesu jest obowiązkiem spoczywającym na spersonifikowanej korporacji.

Strategia taka jest jednak nie tylko niekonieczna dla realizacji celów stawianych w ramach społecznej odpowiedzialności biznesu, lecz także powoduje wiele trudności teoretycznych i problemów praktycznych, wspomnianych wcześniej w artykule. Personifikacja korporacji jest rozwiązaniem niekoniecznym, gdyż koncepcja CSR w ramach społecznych oczekiwań uwzględnia moralne przekonania poszczególnych ludzi (indywidualizm normatywny). To w odniesieniu do indywidualnych ludzi można mówić o podmiotowości moralnej i moralnych

8 Teoria interesariuszy jest zakresowo szersza i może być wykorzystywana zarówno w koncepcji CSR, jak i w etyce biznesu, teorii organizacji lub zarządzaniu strategicznym [Freeman i McVea 2001]. 
obowiązkach, to tam jest miejsce na stosowanie teorii etycznych. Idea społecznych oczekiwań może być traktowana jako swoisty pas transmisyjny, przesyłający wymagania oparte na przekonaniach moralnych od indywidualnych ludzi do instytucji, którą jest korporacja.

Dążenie do nadania korporacji moralnego statusu po to, by można było utrzymywać spójny pogląd, że za wywołane skutki zawsze odpowiada jakiś podmiot, np. korporacja, w konsekwencji prowadzi do prób przyznania tego typu bytom nie tylko obowiązków, ale również korespondujących z nimi praw. Autonomia moralna zwykłych ludzi łączy się z takimi prawami jak prawo do życia, wolności, własności, partycypacji politycznej itp. Pytanie brzmi, czy moglibyśmy się zgodzić na przyznanie analogicznych praw korporacjom. Rozwiązanie, które zaproponowali Pettit i List, sprowadzające się do uznania, że ze względu na posiadanie autonomii epistemicznej przy jednoczesnym braku autonomii ontycznej korporacja jest osobą sztuczną, choć nie fikcyjną, budzi pewne wątpliwości, o czym wspomniano w artykule [Kwarciński 2016].

W związku z tym dla realizacji oczekiwań społecznych nie jest konieczne personifikowanie korporacji. Jeśli już, mając na względzie argumentację pragmatyczną i wymóg realizacji odpowiedzialności wyrównawczej, chcielibyśmy przyjąć jakąś formę moralnej odpowiedzialności korporacji, to najbardziej owocne wydają się stanowiska unikające personifikowania korporacji, które odwołują się do idei systemu moralnie znaczącego lub kultury organizacyjnej.

\section{Zakończenie}

Analiza argumentacji wykazała, że w dyskusji na temat możliwości i sensowności przypisywania korporacjom odpowiedzialności moralnej stosowane są przede wszystkim argumenty z analogii oraz argumenty pragmatyczne. Często również wskazuje się na trudności teoretyczne każdego ze stanowisk. Za zwolennikami personifikowania korporacji najmocniej przemawia argumentacja wskazująca na możliwość uwzględnienia w procesie decyzyjnym korporacji stanowiska słabo reprezentowanych grup interesariuszy. Przeciwnicy przypisywania korporacjom statusu moralnego są natomiast najbardziej przekonujący, wskazując, że konsekwencją tego posunięcia mogłoby być przyjęcie nie tylko obowiązków, ale i praw przynależnych zwykłym ludziom. Zyskują więc na znaczeniu strategie dopuszczające moralną odpowiedzialność korporacji bez jednoczesnego przyznawania jej moralnej podmiotowości.

Stanowiska unikające personifikowania korporacji stają się szczególnie warte uwagi, gdy uświadomimy sobie, że ani teoria interesariuszy, ani koncepcja CSR, w ramach której formułowane są oczekiwania społeczne wobec korporacji, nie 
wymagają przypisywania jej moralnej podmiotowości. Co więcej, nadawanie korporacji statusu moralnego prowadzić może do niepotrzebnego komplikowania wspomnianych teorii.

W związku z tym, czy zrekapitulowana w artykule [Kwarciński 2016] i przeanalizowana $\mathrm{w}$ niniejszej pracy dyskusja na temat personifikowania korporacji jest w ogóle istotna. Odpowiedź wydaje się pozytywna, i to co najmniej z dwóch powodów. Po pierwsze dyskusja ta pokazuje ograniczenia, przed jakimi stają, i problemy, z którymi muszą się liczyć zwolennicy wszystkich wyróżnionych stanowisk. Po drugie strategia unikająca personifikowania korporacji uświadamia nam, że można rozwijać pożądane społecznie koncepcje korporacji i strategie zarządzania nimi, przyjmując minimalistyczne założenia ontologiczne, epistemologiczne i moralne.

Jeżeli jednak opowiemy się za wspomnianym minimalizmem założeń, czy nie prowadzi to do wyrugowania teorii moralnej (etyki) z rozważań dotyczących korporacji? Wydaje się, że nie, gdyż poza korporacją jako swoistym konglomeratem jednostek mamy przecież realnych ludzi (pracowników), indywidualnych interesariuszy czy obywateli, których przekonania moralne można i należy analizować z punktu widzenia teorii etycznych.

\section{Literatura}

Ashman I., Winstanley D. [2007], For or Against Corporate Identity? Personification and the Problem of Moral Agency, ,Journal of Business Ethics”, vol. 76, nr 1, https:// doi.org/10.1007/s10551-006-9270-7.

Carroll A. [1979], A Three-dimensional Conceptual Model of Corporate Performance, „The Academy of Management Review”, vol. 4, nr 4.

Dempsey J. [2013], Corporations and Non-Agential Moral Responsibility, „Journal of Applied Philosophy”, vol. 30, nr 4, https://doi.org/10.1111/japp.12029.

Donaldson T., Preston L.E. [1995], The Stakeholder Theory of the Corporation: Concepts, Evidence, and Implications, „The Academy of Management Review”, vol. 20, nr 1, https://doi.org/10.5465/AMR.1995.9503271992.

Ewin R.E. [1991], The Moral Status of the Corporation, „Journal of Business Ethics”, vol. 10, nr 10, https://doi.org/10.1007/BF00705709.

Frederick W.C. [1994], From CSR1 to CSR2: The Maturing of Business-and-Society Thought, „Business \& Society”, vol. 33, nr 2, https://doi.org/10.1177/000765039403300202.

Freeman R.E. [1984], Strategic Management: A Stakeholder Approach, HarperCollins College Div.

Freeman R.E., McVea J. [2001], A Stakeholder Approach to Strategic Management, Darden Graduate School of Business Administration, University of Virginia, Working Paper No. 01-02.

French P.A. [1997], Spótka jako podmiot moralny, tłum. J. Sójka [w:] Etyka biznesu. Z klasyki wspótczesnej myśli amerykańskiej, red. L.V. Ryan CSV, J. Sójka, W drodze, Poznań. 
Friedman M. [1970], The Social Responsibility of Business Is to Increase Its Profits, „The New York Times Magazine”, September 13.

Friedman M. [1997], Społeczna powinnością biznesu jest pomnażanie zysków, tłum. J. Sójka [w:] Etyka biznesu. Z klasyki współczesnej myśli amerykańskiej, red. L.V. Ryan CSV, J. Sójka, W drodze, Poznań.

Gibson K. [2000], The Moral Basis of Stakeholder Theory, „Journal of Business Ethics”, vol. 26, nr 3, https://doi.org/10.1023/A:1006110106408.

Goodpaster K., Matthews Jr. J. [1997], Czy spółka może mieć sumienie?, tłum. E. Dratwa [w:] Etyka biznesu. Z klasyki współczesnej myśli amerykańskiej, red. L.V. Ryan CSV, J. Sójka, W drodze, Poznań.

Harrison J., Bosse D., Phillips R. [2012], Managing for Stakeholders, Stakeholder Utility Functions, and Competitive Advantage [w:] New Directions in Business Ethics, vol. IV, Sage, Los Angeles.

Harrison J.S., Freeman R.E., Cavalcanti Sá de Abreu M. [2015], Stakeholder Theory As an Ethical Approach to Effective Management: Applying the Theory to Multiple Contexts, ,Review of Business Management”, vol. 17, nr 55, https://doi.org/10.7819/ rbgn.v17i55.2647.

Hindriks F. [2014], How Autonomous Are Collective Agents? Corporate Rights and Normative Individualism, „Erkenntnis”, vol. 79, suppl. 9, https://doi.org/10.1007/s10670014-9629-6.

Kwarciński T. [2016], Spór o możliwość i sensowność przypisywania korporacjom moralnej odpowiedzialności. Stan badań, ,Zeszyty Naukowe Uniwersytetu Ekonomicznego w Krakowie", nr 4(952), https://doi.org/10.15678/ZNUEK.2016.0952.0406.

Ladd J. [1997], Moralność a ideat racjonalności w organizacjach formalnych, tłum. J. Sójka [w:] Etyka biznesu. Z klasyki współczesnej myśli amerykańskiej, red. L.V. Ryan CSV, J. Sójka, W drodze, Poznań.

Manning R. [1988], Dismemberment, Divorce and Hostile Takeovers: A Comment on Corporate Moral Personhood, ,Journal of Business Ethics”, vol. 7, nr 8, https://doi. org/10.1007/BF00382798.

Miles S. [2015], Stakeholder Theory Classification: A Theoretical and Empirical Evaluation of Definitions, ,Journal of Business Ethics”, https://doi.org/10.1007/s10551-015-2741-y.

Moore G. [1999], Corporate Moral Agency: Review and Implications, ,Journal of Business Ethics", vol. 21, nr 4, https://doi.org/10.1023/A:1006020214228.

Pettit P., List Ch. [2011], Group Agency. The Possibility, Design and Status of Corporate Agents, Oxford University Press.

Pfeiffer R.S. [1990], The Central Distinction in the Theory of Corporate Moral Personhood, ,Journal of Business Ethics”, vol. 9, nr 6, https://doi.org/10.1007/BF00382840.

Ranken N.L. [1987], Corporations as Persons: Objections to Goodpaster's 'Principle of Moral Projection', „Journal of Business Ethics”, vol. 6, nr 8, https://doi.org/10.1007/ BF00705779.

Velasquez M.G. [1997], Dlaczego spółki nie sa za nic moralnie odpowiedzialne?, tłum. E. Dratwa, J. Sójka [w:] Etyka biznesu. Z klasyki współczesnej myśli amerykańskiej, red. L.V. Ryan CSV, J. Sójka, W drodze, Poznań.

Velasquez M.G. [2003], Debunking Corporate Moral Responsibility, „Business Ethics Quarterly", vol. 14, nr 4, https://doi.org/10.5840/beq200313436.

Wood S. [2011], Four Varieties of Social Responsibility: Making Sense of the „, Sphere of Influence” and "Leverage” Debate via the Case of ISO 26000, „Osgoode CLPE Research Paper 14/2011", vol. 7, nr 4. 


\section{On the Sense and Practicability of Ascribing Moral Responsibility to Corporations - Critical Analysis \\ (Abstract)}

The article seeks to determine if corporations can be expected to act in a morally responsible manner and what possible factors can make such a view sensible. In the article, I analyse three different views of corporate moral responsibility: first, that it is not possible; second, that such a responsibility is based on an appropriately understood conception of moral corporate subjectivity; and, third, that it is not necessary to acknowledge its moral subjectivity in order to assign moral responsibility to a corporation. I consider different types of argumentation, the implications regarding stakeholder theory and social expectations included in the concept of corporate social responsibility.

Keywords: moral responsibility, group agency, stakeholder theory, corporate social responsibility. 